\title{
HEART FAILURE DUE TO EXTREME OBESITY
}

\author{
BY \\ T. B. COUNIHAN
}

From the Department of Medicine, Postgraduate Medical School of London

Diseases that restrict the respiratory excursions of the chest for a long period may lead to cor pulmonale but obesity is not usually recognized among them. The following report is of a case of cor pulmonale from extreme obesity.

\section{Case Report}

A woman, aged 40 , was admitted to hospital with the complaints of obesity and recent dyspnœa and cyanosis. She had been moderately obese in childhood, and weighed $11 \mathrm{st} .3 \mathrm{lb}$. (71 kg.) in 1935 and 13 st. $2 \mathrm{lb} .(83 \mathrm{~kg}$.) in 1939 . Thereafter her weight increased grossly and in 1951 she weighed about 20 st. (127 kg.). A low calorie diet and dextro-amphetamine temporarily halted the increase, but she began again to put on still more weight. Otherwise, she had always enjoyed good health and remained well until six months before admission.

At that time, she had had a severe cough, without sputum, for about three weeks. Afterwards, she became still stouter and noticed a hard thickening of the substance of the anterior abdominal wall which later spread up over the front of the chest. Her sister noticed that when the patient laughed her face became blue. She developed increasing dyspnœa, especially on effort; shortly before admission she could just manage one flight of stairs.

On admission her weight was approximately 26 stones $(364 \mathrm{lb}$. or $165 \mathrm{~kg}$.) (height $5 \mathrm{ft} .8 \mathrm{in}$.). Her girth was enormous. She was encased in masses of fatty tissue which over the torso had a hard unyielding quality. There was elephantiasis of the mons veneris and labia. By comparison with the torso the limbs were slender, though themselves very adipose. There was peau d'orange on the lower abdomen and on the pendulous breasts. The skin nowhere pitted very much and then only after prolonged, firm pressure and its appearance and texture resembled those of lymphœdema, especially on the trunk.

Her face was suffused and there was moderate cyanosis. She was not dyspnœic at rest, but the effort of moving herself about in bed made her very breathless. The jugular venous pressure could not be truly assessed but was probably grossly raised. There was gross papillodema with enormously distended retinal veins and numerous retinal hæmorrhages chiefly distributed in relation to the veins. The ocular fundi were most reminiscent of the appearances seen sometimes in advanced emphysema heart failure.

No abnormality could be detected on examination of the heart and lungs themselves. The blood pressure was 130/90. The electrocardiogram showed general low voltage. The oxygen saturation of the blood (by ear oximetry) was 57 per cent, increasing to 79 per cent on inhalation of oxygen. The hæmoglobin was $15 \cdot 2 \mathrm{~g}$. No vital capacity greater than the tidal air could be recorded.

Oxygen inhalations, digitalis and a mersalyl injection did little to benefit her condition and she died suddenly five days after admission.

Post-mortem Examination. Although the body had been in the refrigerator the internal organs were still warm owing to the insulating power of the adipose tissues and a certain amount of autolysis had taken place. The peritoneal sac contained a litre of ascitic fluid. The heart weighed $640 \mathrm{~g}$. There was slight atheroma of the right coronary artery but all the coronary vessels were patent. The heart valves were normal. The right ventricle was $7 \mathrm{~mm}$. thick in its outflow pathway and the left ventricle $25 \mathrm{~mm}$. The cavities of both ventricles were distended. The bronchi were free from obstruction. The lungs were normal though partly autolysed (right $620 \mathrm{~g}$., left $620 \mathrm{~g}$.). The pulmonary arteries contained no thrombi. The liver $(2700 \mathrm{~g}$.) was fatty and showed areas of autolysis, particularly in relation to the hepatic veins. The spleen $(630$ g.) was congested. The kidneys each weighed $380 \mathrm{~g}$.; on the cut surface there were numerous 
golden granules. The adrenal glands were autolysed; their total weight, with some fat attached, was $22 \mathrm{~g}$. The thyroid $(60 \mathrm{~g}$.) contained a calcified nodule in the right upper pole. The pituitary appeared normal. The brain weighed $1275 \mathrm{~g}$. and showed engorgement of the vessels over the cerebrum and congestion of the intra-cerebral small vessels.

Histologically, in the skin of the abdominal wall the collagen of the corium was broken up and thickened, and the appearances were those of lymphœdema. There was no fatty degeneration of the myocardial cells. The lungs, which were congested, showed evidence of slight emphysema. There was no bronchitis and the small branches of the pulmonary arteries were normal. The liver and kidneys showed fatty infiltration. Aggregates of fat in the kidney tubules were found to form the golden granules noted with the naked eye on the cut surface. The pituitary and hypothalamus were normal apart from some perivascular œdema in the latter.

\section{Discussion}

The clinical picture was that of cor pulmonale resembling especially emphysema heart failure, but none of the recognized causes of cor pulmonale was present. The embarrassment of respiratory expansion by the enormous mass of fat led to cardiac insufficiency, probably at the time of an upper respiratory tract infection six months before death. The infection cleared up but, when once cardiac failure had begun, the accumulation of odema amid the adipose tissue of the body wall made a hard and unyielding cuirass. So the relatively slight restriction of respiration from fat alone was changed to a progressive immobilization of the chest from tensely odematous fat. Increments of œdema further inflating the adipose tissues splinted the chest, the degree of heart failure increased and still more œdema of the parietes resulted. At the time of the patient's admission to hospital her vital capacity was already reduced to the volume of her tidal air, and treatment at that late stage failed to halt the self-aggravating process.

The great weight of the heart due to hypertrophy of both ventricles was a remarkable part of a general splanchnomegaly which likewise affected such lean organs as the kidneys. Left ventricular failure causing cor pulmonale reveals itself at necropsy in pulmonary œdema and the freedom of the lungs from œdema in this patient exonerates that ventricle. The bronchi and lungs showed no intrinsic disease other than mild emphysema and the pulmonary arteries showed no obliterative process.

The condition described here has an analogy in cardiorespiratory failure occurring in kyphoscoliosis. Sieker et al. (1955) have briefly reported similar cardiopulmonary failure in four patients with marked obesity. Pulmonary arterial pressures were moderately raised and pulmonary capillary pressures were normal. Reduction of weight brought improvement.

\section{Summary}

A case of extreme adiposity, leading to cardiorespiratory failure, is reported. When this had started, the adipose tissues of the body wall became tense with cardiac odema and immobilized the chest, producing the clinical picture of cor pulmonale.

\section{Reference}

Sieker, H. O., Estes, E. H., Jr., Kelser, G. A., and McIntosh, H. D. (1955). J. Clin. Invest., 34, 916. 